\title{
Performance Evaluation of Tractor Operated Plastic Mulch Laying Equipment for Black and Silver Colored Plastic Mulches
}

\author{
Siddesh Marihonnappanavara ${ }^{1}$, M. Veerangouda ${ }^{1}$, K.V. Prakash ${ }^{2}$, \\ Sunil Shirwal ${ }^{3}$ and B. Maheshwara Babu ${ }^{4}$
}

${ }^{1}$ CAE, ${ }^{2}$ Dept. REE, ${ }^{3}$ Department FMPE, ${ }^{4}$ Dept. SWE, College of Agricultural Engineering, University of Agricultural Sciences, Raichur 584 104, Karnataka, India

*Corresponding author

\section{A B S T R A C T}

\begin{tabular}{|c|}
\hline Keywords \\
\hline $\begin{array}{l}\text { Plastic mulches, } \\
\text { Soil moisture, Soil } \\
\text { temperature, Press } \\
\text { wheel assembly }\end{array}$ \\
\hline Article Info \\
\hline $\begin{array}{l}\text { Accepted: } \\
17 \text { November } 2018 \\
\text { Available Online: } \\
10 \text { December } 2018\end{array}$ \\
\hline
\end{tabular}

Keywords

Plastic mulches, Soil moisture, Soil temperature, Press wheel assembly

icle Info

Accepted:

Available Online:

\section{Introduction}

Plasticulture research and documentation largely focus on the impact of plastics on horticultural crops and their associated yields rather than the science behind machinerydesigned specifically for the planting and harvesting processes.

The word plastic comes from the Greek word "plastikos", which means 'able to be moulded into different shapes' (Joel, 1995). Mulch helps in preventing the establishment of weeds

\begin{abstract}
A tractor operated plastic mulch laying equipment was developed in the department of Farm Machinery and Power Engineering, CAE, UAS Raichur. It was developed to mechanize the conventional plastic mulching operation. A plastic mulch roller was mounted on the main frame of equipment. A $35 \mathrm{hp}$ tractor was used as a power unit for both plastic mulching and drip laying operations. The plastic mulch laying equipment was tested in the field condition. Effect of operational parameters viz. type of material, width of plastic mulch and forward speed on soil moisture content of plastic mulched soil beds after 10,20 and 30 days of plastic mulch laying were recorded. It was observed that soil moisture content was increased as the width of the material increased for both types of materials. However, higher moisture content was observed for the black colored plastic ch for $1200 \mathrm{~mm}$ width of plastic mulch at all the forward speeds. Theoretical field capacity of tractor operated plastic mulch laying was found to be $0.36 \mathrm{ha} \mathrm{h}^{-1}$. Effective field capacity of tractor operated plastic mulch laying was found to be $0.24 \mathrm{ha} \mathrm{h}^{-1}$.
\end{abstract}

in many vegetable crops. Black sheet mulches prevent most weeds by excluding light. Intact plastic and other materials control essentially all annual weeds except at planting holes and mulch edges, where additional control measures are needed. Along with enhanced moisture regulation, mulch allows for greater control of nutrients and fertilizer loss since leaching is reduced (Scott and Gilead, 1995).

Plastic films are laid before crop planting or transplanting. This includes preparation of seed bed, spread mulch film and anchoring of 
edges of film. Raised seed bed has to be prepared for plastic mulching (Scott, 1995). To perform this operation, two persons are required for laying over the soil bed, while one more person is required behind them to shovel the soil onto the edges of the mulch. These operations when done by manually become very time consuming, labour intensive, tedious and costly. Manual method is economical for the small fields but not economical for the large fields.

The plastics we use today are made from inorganic and organic raw materials, such as carbon, silicon, hydrogen, nitrogen, oxygen and chloride. The basic materials used for making plastics are extracted from oil, coal and natural gas (Seymour, 1989). Plastics are resistant against microbial attack, since their short time of presence in nature evolution could not design new enzyme structures capable of degrading synthetic polymers (Mueller, 2001). When compared to other mulches, plastic mulches are completely impermeable to water; it therefore prevents direct evaporation of moisture from the soil and thus limits the water losses and soil erosion over the surface. The suppression of evaporation also has a supplementary effect; it prevents the rise of water containing salt, which is important in countries with high salt content water resources.

Plastic mulch can be used effectively to modify soil temperature. Black or clear mulches intercept sunlight, which warms the soil. White or aluminum mulch reflects the sun's heat and keeps the soil cooler. Black mulch applied to the planting bed will warm the soil and promote faster growth in early season, which generally leads to earlier harvest. Mulches help prevent soil water loss due to evaporation from the soil surface. Drip irrigation is often placed underneath mulches to provide a means for precise management of soil moisture. This can reduce irrigation frequency and amount, and may help reduce the incidence of moisture-related physiological disorders such as blossom end rot and fruit cracking.

In modern agriculture, tractor has become one of the major sources of power which is generally used for majority of the agricultural operations like irrigation, land development, tillage, sowing, harvesting, threshing and transportation. Tractors help in reducing the time required for these operations. Hence, it has become the integral part of mechanized agriculture. Plastic mulching by conventional method requires more human labour, more time and more cost of operation. Keeping the above facts in view present study has been undertaken to develop tractor operated plastic mulch laying equipment. This paper reveals the performance of the developed tractor operated plastic mulch laying equipment.

\section{Materials and Methods}

Tractor operated plastic mulch laying equipment consist of plastic mulch roller assembly, drip roll carrier assembly, soil covering device and press wheel assembly. A plastic mulch roll carrier (1.40 meter in length) was selected based on the width of plastic mulching on raised soil beds. The width of the plastic roller can be adjusted as per the mulching requirement. Plastic mulch used for the study is of two type viz., Silver colour and Black colour. Thickness of the both the materials used were of 30 micron. Both the plastic mulch used is selected with three different widths i.e., $1200 \mathrm{~mm}, 1000 \mathrm{~mm}$ and $900 \mathrm{~mm}$. The light absorption (\%) of silver colour plastic mulch is $51 \%$ and light reflection (\%) is $49 \%$ whereas, light absorption (\%) of black colour plastic mulch is $100 \%$ and light reflection $(\%)$ is $0 \%$. The drip roller is to be slide onto the drip roll carrier so that drip emitter will be turned up toward plastic mulch. The plastic mulch and 
drip lateral was placed under the press wheel assembly before going to start the plastic mulch laying operation. The soil covering assembly was adjusted properly to lift and through the soil over the edges of the plastic mulch to make air tight plastic mulched soil beds. Press wheels have been made to run at the bottom of the trench and not on the side to stretch the plastic properly. The prototype of tractor operated plastic mulch laying equipment was fabricated based on the design. The prototype consists of main frame, plastic mulch roller assembly, drip roll carrier assembly, soil covering device and press wheel assembly. A schematic view of tractor operated plastic mulch laying equipment is shown in Figure 1.

Specifications of developed tractor operated plastic mulch laying equipment were given in Table 1 and specification of selected tractor was represented in Table 2. The following are the relevant machine parameters, which imposed limitations on the development aspects of the tractor operated plastic mulch laying equipment.

\section{Speed of operation}

The tractor is operated at selected speeds of 2.0 (F1), $3.0(\mathrm{~F} 2)$ and $4.0(\mathrm{~F} 3) \mathrm{km} \mathrm{h}^{-1}$ for plastic mulch laying operation. Before conducting every experiment the travel speed of tractor was calibrated for required forward speed for mulching. These travel speeds were achieved by adjusting engine throttle position and gear setting. For calibration of speed of operation, a test trial conducted in same field condition in order to avoid errors. The tractor was operated at all the gear and at three different throttle position. Finally, it was concluded that the gear $F_{1}, F_{2}$ and $F_{3}$ gives 2.0, 3.0 and $4.0 \mathrm{~km} \mathrm{~h}^{-1}$ respectively. The speed of operation was measured during calibration by the long boundary of the test plot, two poles $20 \mathrm{~m}$ apart were placed approximately in the middle of the test run. On the opposite side also two poles were placed in similar position of $20 \mathrm{~m}$ apart so that all four corners of a rectangle, parallel to one long side of the test plot. The speed was calculated as the ratio of the distance $(20 \mathrm{~m})$ to the time taken for the tractor to travel the same distance.

\section{Width of operation}

The width of mulching operation will be decided on the basis of row to row spacing and plant to plant spacing within the raised bed. Width of operation of tractor operated plastic mulch laying equipment was measured randomly at different locations in the field. The composite width of operation was measured at five equidistant places in the direction of travel and the average working width of operation was recorded.

\section{Depth of operation}

The depth of operation of the tool plays an important role in the plastic mulch laying. This helps to decide the soil covering device (M.B. plough bottom) parameters for the operational limitations like speed and draft. The depth of operation was maintained constant throughout the field by setting up of hydraulic lever position, based on plastic mulch laying requirements.

\section{Operational parameters}

The following are the relevant operational parameters, which imposed limitations on the development aspects of the tractor operated plastic mulch laying equipment.

\section{Theoretical field capacity}

It is the rate of field coverage of the implement, based on 100 per cent of time at the rated speed and covering 100 per cent of its rated width. Theoretical field capacity was calculated by using following formula (Mehta et al., 2005). 
$\mathrm{T} F \mathrm{C}=\frac{\mathrm{S} \times \mathrm{W}}{10}$ Where,

Where,

T.F.C. $=$ theoretical field capacity, ha $\mathrm{h}^{-1}$

$\mathrm{W}=$ theoretical width of mulch laying equipment, $m$

$\mathrm{S}=$ speed of operation, $\mathrm{km} \mathrm{h}^{-1}$

\section{Effective field capacity}

It is the actual area covered by the implement, based on its total time consumed and its width. For calculating effective field capacity, the time consumed for actual work and loss for other activities such as turning and cleaning of blades when clogged with weeds were taken in to consideration. Effective field capacity was calculated by following formula (Mehta $e t$ al., 2005).

E.F.C. $=\frac{A}{T_{p}-T_{n}} \times 100$

Where,

E.F.C. $=$ effective field capacity, ha $\mathrm{h}^{-1}$

$\mathrm{A}=$ area, ha

$\mathrm{T}_{\mathrm{p}}=$ productive time, $\mathrm{h}$

$T_{n}=$ nonproductive time, $\mathrm{h}$ (Time loss for turning and cleaning blades)

\section{Field efficiency}

It is the ratio of effective field capacity and theoretical field capacity expressed in percent. It was calculated by following formula (Mehta et al., 2005).

Field efficiency $(\%)=\frac{\text { E.F.C. }}{\text { T.F.C. }} \times 100$ Where,

E.F.C. $=$ effective field capacity

T.F.C. $=$ theoretical field capacity

\section{Fuel consumption}

Fuel consumption is the amount of fuel used per unit distance. The fuel tank is filled to its capacity before and after the operation. Amount of refilling after the operation is measured which is the actual fuel consumption.

\section{Wheel slip}

It is the relative movement of the wheel in the direction of travel for a given distance under load and at no load condition.

It can be calculated by the formula (Sahay, 2010).

Wheel slip (\%) $=\frac{\mathrm{N}_{1}-\mathrm{N}_{2}}{\mathrm{~N}_{1}} \times 100$

Where,

$\mathrm{N}_{1}=$ No. of revolutions of driving wheels for a given distance under load and

$\mathrm{N}_{0}=$ No. of revolutions of driving wheels for the same distance at no load

In most of the cases, the tool has no effect on slip at different levels of forward speed (Manian, 1997). Hence the measurement of slip was neglected due to the negative draft.

\section{Draft of equipment}

Total draft exerted on the equipment was computed using the formula. (Anon. 1995)

$D=D_{1}-D_{2}$

Where,

$D=$ draft of equipment, $\mathrm{kg}$ or $\mathrm{N}$

$D_{1}=$ draft of equipment when equipment in operating condition, $\mathrm{kg}$ or $\mathrm{N}$

$D_{2}=$ draft of equipment when equipment in not operating condition, $\mathrm{kg}$ or $\mathrm{N}$ 
Optimization of operational parameters of tractor operated plastic mulch laying equipment

The tractor operated plastic mulch laying equipment was tested in field condition to determine the optimum operational parameters for plastic mulch laying.

The parameters selected for optimization include three forward speeds $\left(2.0 \mathrm{~km} \mathrm{~h}^{-1}, 3.0\right.$ $\mathrm{km} \mathrm{h}^{-1}$ and $4.0 \mathrm{~km} \mathrm{~h}^{-1}$ ), two types of material (silver and black color) and three types of width of material $(1200 \mathrm{~mm}, 1000 \mathrm{~mm}$ and $900 \mathrm{~mm}$ ). The effect of operational parameters was studied to evaluate the performance of tractor operated plastic mulch laying equipment in terms of soil moisture content.

\section{Results and Discussion}

Effect of type of material and width of plastic mulch on moisture content at different forward speed after $\mathbf{1 0}$ days of laying plastic mulch

The plastic mulch laying equipment was tested in the field condition. Effect of operational parameters viz. type of material, width of plastic mulch and forward speed on moisture content of plastic mulched soil beds after 10 days of plastic mulch laying are presented in Table 3. It was observed that, the moisture content of plastic mulch with silver colored plastic varied from $17.20 \%$ to $18.30 \%$ with different widths of plastic mulch and at different forward speeds.

Maximum moisture content of $18.3 \%$ was recorded at a forward speed of $3.0 \mathrm{~km} \mathrm{~h}^{-1}$ with $1200 \mathrm{~mm}$ width of plastic mulch while it was minimum $17.20 \%$ at forward speed of $2.0 \mathrm{~km}$ $\mathrm{h}^{-1}$ with $900 \mathrm{~mm}$ width of plastic mulch. It was also observed that, with black colored plastic mulch the moisture content varied in the range of $18.50 \%$ to $20.10 \%$ with different widths of plastic mulch and at different forward speeds. Maximum moisture content of $20.10 \%$ was recorded at forward speed of $3.0 \mathrm{~km} \mathrm{~h}^{-1}$ with $1200 \mathrm{~mm}$ width of plastic mulch while it was minimum $18.50 \%$ at forward speed of $2.0 \mathrm{~km}$ $\mathrm{h}^{-1}$ with $900 \mathrm{~mm}$ width of plastic mulch. The effect of type of material, width of plastic mulch and forward speed on moisture content of soil at 2.0, 3.0 and $4.0 \mathrm{~km} \mathrm{~h}^{-1}$ have been presented in Figure 2 and 3, respectively. It was observed that, from these figures the moisture content increased as the width of the material increased for both types of materials. However, higher moisture content was observed for the black colored plastic mulch for $1200 \mathrm{~mm}$ width of plastic mulch at all the forward speeds.

Effect of type of material and width of plastic mulch on moisture content at different forward speed after 20 days of laying of plastic mulch

Effect of operational parameters viz. type of material, width of plastic mulch and forward speed on soil moisture content after 20 days of laying plastic mulch are presented in Table 4. It was observed that, the soil moisture content with silver colored plastic mulch varied from $17.00 \%$ to $17.90 \%$ with different width of plastic mulch and at different forward speeds.

Maximum moisture content of $17.90 \%$ was recorded at a forward speed of $3.0 \mathrm{~km} \mathrm{~h}^{-1}$ with $1200 \mathrm{~mm}$ width of plastic mulch while it was minimum $17.00 \%$ at forward speed of $2.0 \mathrm{~km}$ $\mathrm{h}^{-1}$ with $900 \mathrm{~mm}$ width of plastic mulch. It was also observed that, with black colored plastic mulch the soil moisture content varied in the range $18.40 \%$ to $19.40 \%$ with different width of plastic mulch and at different forward speeds. Maximum moisture content of 19.40 $\%$ is recorded at forward speed of $3.0 \mathrm{~km} \mathrm{~h}^{-1}$ with $1200 \mathrm{~mm}$ width of plastic mulch while it was minimum $18.40 \%$ at forward speed of 2.0 $\mathrm{km} \mathrm{h}^{-1}$ with $900 \mathrm{~mm}$ width of plastic mulch. 
Table.1 Specifications of tractor operated plastic mulch laying equipment

\begin{tabular}{|c|c|c|}
\hline Sl. No & Parameter & Description \\
\hline \multicolumn{3}{|c|}{ Power source } \\
\hline 1 & Power source used & Tractor \\
\hline 2 & Make & Mahindra Arjun \\
\hline 3 & Model & $595 \mathrm{DI}$ \\
\hline 4 & Drive wheels & \multirow[b]{2}{*}{ Pneumatic, traction } \\
\hline & - $\quad$ Type of tires & \\
\hline & $\checkmark$ Size, $\mathrm{cm}$ & $14.9-28$ \\
\hline & $\checkmark$ Track width, mm & 1425 \\
\hline \multicolumn{3}{|c|}{ Plastic roll assembly } \\
\hline 5 & 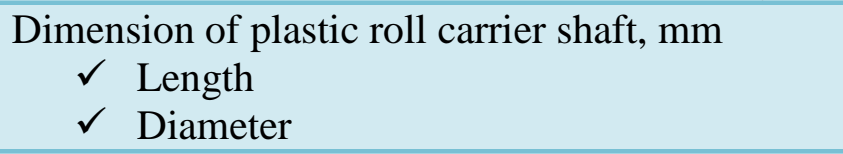 & $\begin{array}{l}\checkmark 140 \\
\checkmark 25\end{array}$ \\
\hline 6 & Number of pedestal for plastic roll assembly & 2 \\
\hline 7 & Theoretical width of operation of equipment, $\mathrm{mm}$ & $900-1200$ \\
\hline 8 & Number of press wheels & 2 \\
\hline 9 & Number of mould board plough bottoms & 2 \\
\hline \multicolumn{3}{|c|}{ Drip roll assembly } \\
\hline 10 & $\begin{array}{l}\text { Dimension of drip roll carrier shaft, } \mathrm{mm} \\
\checkmark \quad \text { Length } \\
\checkmark \quad \text { Diameter }\end{array}$ & $\begin{array}{ll}\checkmark & 1000 \\
\checkmark & 25\end{array}$ \\
\hline 11 & Number of support wheels & 2 \\
\hline 12 & Number of pedestal for drip roll shaft & 2 \\
\hline 13 & Number of down pipes & 1 \\
\hline
\end{tabular}

Table.2 Specification of selected tractor

\begin{tabular}{|l|l|}
\hline Name of Manufacturer & Mahindra and Mahindra \\
\hline Make & Mahindra sarpanch \\
\hline Model & $595 \mathrm{DI}$, \\
\hline Year of manufacture & 2004 \\
\hline Rated engine speed, rpm & 2600 \\
\hline Number of cylinders/ disposition & Four stroke, Direct injection, Water cooled \\
\hline Max. P.T.O power, $\mathbf{k W}$ & 42 \\
\hline Nominal P.T.O speed, rpm & 5406 \\
\hline No. of P.T.O splines & 6 \\
\hline Specific fuel consumption, g/hp h & 180 \\
\hline Drive wheels & Pneumatic, Traction \\
\hline Front tire size & $6.5-20$ \\
\hline Rear tire size & $16.9-28$ \\
\hline Track width, mm & 1425 \\
\hline
\end{tabular}


Table.3 Effect of type of material and width of plastic mulch on moisture content at different forward speed after 10 days of laying plastic mulch

\begin{tabular}{|l|l|l|l|l|l|}
\hline $\begin{array}{l}\text { Sl. } \\
\text { no }\end{array}$ & Type of material & Width of plastic mulch, & \multicolumn{3}{|l|}{ Moisture content, \% } \\
\cline { 3 - 6 } & & & \multicolumn{2}{l|}{ Forward speed, $\left(\mathrm{km} \mathrm{h}^{-1}\right)$} \\
\cline { 3 - 6 } & & & 2 & 3 & 4 \\
\hline $\mathbf{1}$ & Silver color & 1200 & 18.00 & 18.30 & 18.20 \\
\hline & & 1000 & 17.50 & 17.70 & 17.60 \\
\hline \multirow{2}{*}{$\mathbf{2}$} & Black color & 900 & 17.20 & 17.40 & 17.30 \\
\hline & & 1200 & 20.00 & 20.10 & 20.00 \\
\hline & & 1000 & 19.20 & 19.30 & 19.20 \\
\hline & 900 & 18.50 & 18.70 & 18.60 \\
\hline
\end{tabular}

Table.4 Effect of operational parameters viz. type of material, width of plastic mulch and forward speed on soil moisture content after 20 days of laying plastic mulch

\begin{tabular}{|l|l|l|l|l|l|}
\hline $\begin{array}{l}\text { Sl. } \\
\text { no }\end{array}$ & Type of material & \multirow{2}{*}{$\begin{array}{l}\text { Width of plastic mulch, } \\
\text { mm }\end{array}$} & & \multicolumn{3}{|l|}{ Moisture content, \% } \\
\cline { 3 - 6 } & & \multicolumn{2}{l|}{ Forward speed, $\left(\mathrm{km} \mathrm{h}^{-1}\right)$} \\
\hline $\mathbf{1}$ & Silver color & 1200 & 2 & 3 & 4 \\
\hline & & 1000 & 17.80 & 17.90 & 17.85 \\
\hline \multirow{2}{*}{$\mathbf{2}$} & Black color & 900 & 17.30 & 17.40 & 17.35 \\
\hline & & 1200 & 17.00 & 17.10 & 17.05 \\
\hline & 1000 & 19.30 & 19.40 & 19.35 \\
\hline & 900 & 18.90 & 19.00 & 18.95 \\
\hline
\end{tabular}

Table.5 Effect of operational parameters viz. type of material, width of plastic mulch and forward speed on soil moisture content after 30 days of laying plastic mulch

\begin{tabular}{|c|c|c|c|c|c|}
\hline \multirow{3}{*}{$\begin{array}{l}\text { Sl. } \\
\text { no }\end{array}$} & \multirow[t]{3}{*}{ Type of material } & \multirow{3}{*}{$\begin{array}{l}\text { Width of plastic mulch, } \\
\text { mm }\end{array}$} & \multirow{2}{*}{\multicolumn{3}{|c|}{$\begin{array}{l}\text { Moisture content, \% } \\
\text { Forward speed, }\left(\mathrm{km} \mathrm{h}^{-1}\right)\end{array}$}} \\
\hline & & & & & \\
\hline & & & 2 & 3 & 4 \\
\hline \multirow[t]{3}{*}{1} & \multirow[t]{3}{*}{ Silver color } & 1200 & 17.40 & 17.50 & 17.45 \\
\hline & & 1000 & 17.00 & 17.10 & 17.05 \\
\hline & & 900 & 16.80 & 16.90 & 16.85 \\
\hline \multirow[t]{3}{*}{2} & \multirow[t]{3}{*}{ Black color } & 1200 & 18.60 & 18.70 & 18.65 \\
\hline & & 1000 & 18.10 & 18.20 & 18.15 \\
\hline & & 900 & 17.85 & 17.95 & 17.90 \\
\hline
\end{tabular}


Fig.1 Components of developed tractor operated plastic laying equipment

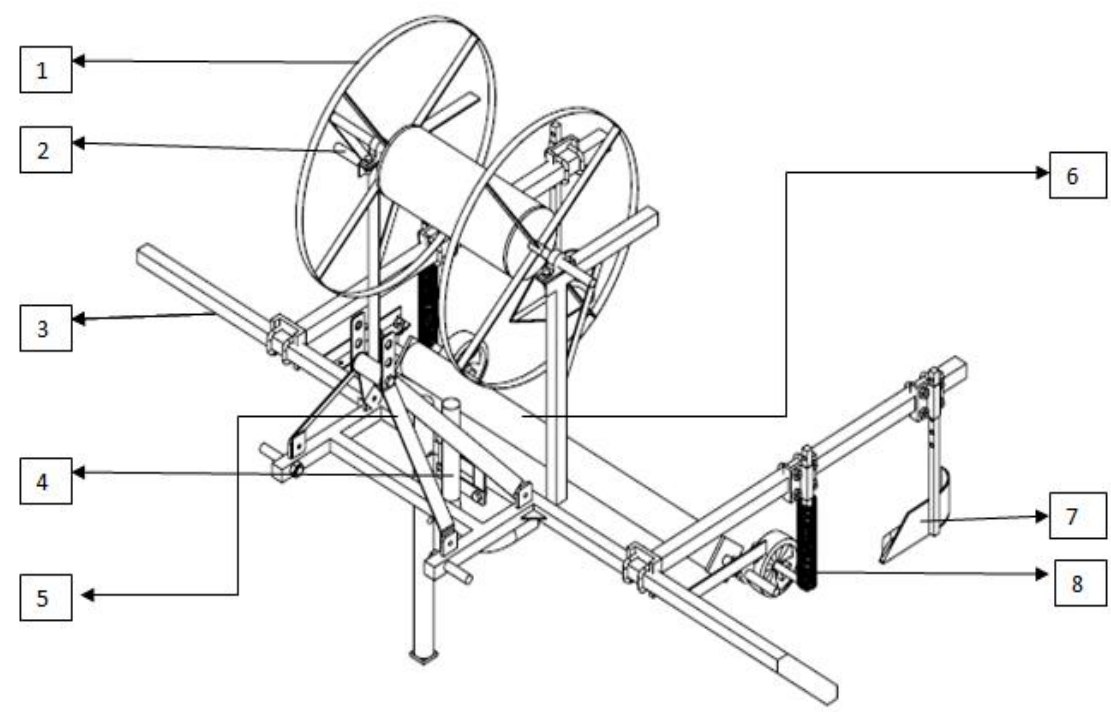

1. Drip lateral assembly; 2. Handle; 3. Main frame; 4. Down pipe; 5. Three point hitch; 6. Plastic roller assembly; 7. Soil covering device; 8 . Press wheel assembly

Fig.2 Effect of width of plastic mulch and forward speed on soil moisture content for silver color plastic mulch after 10 days of laying plastic mulch

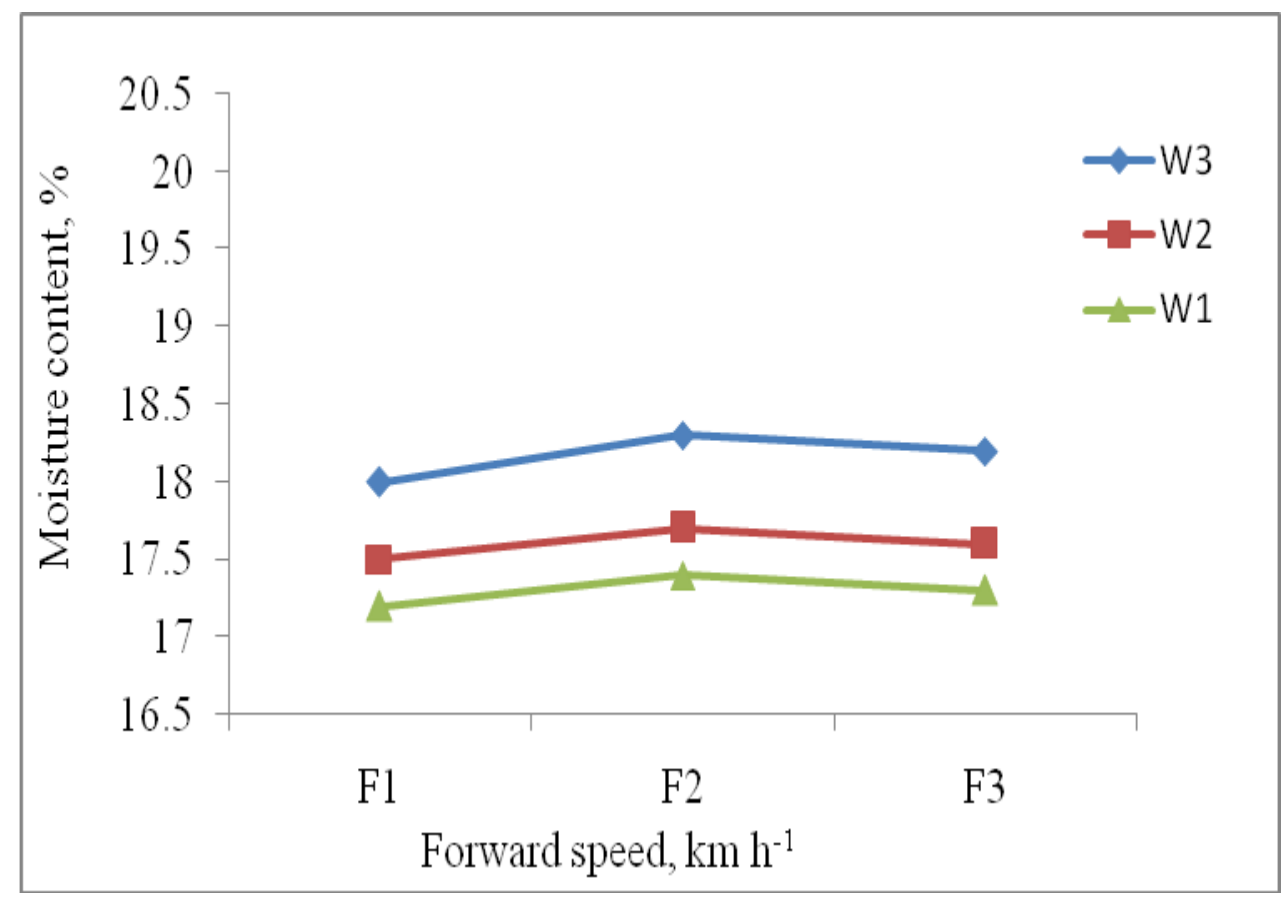


Fig.3 Effect of width of plastic mulch and forward speed on soil moisture content for black color plastic mulch after 10 days of laying plastic mulch

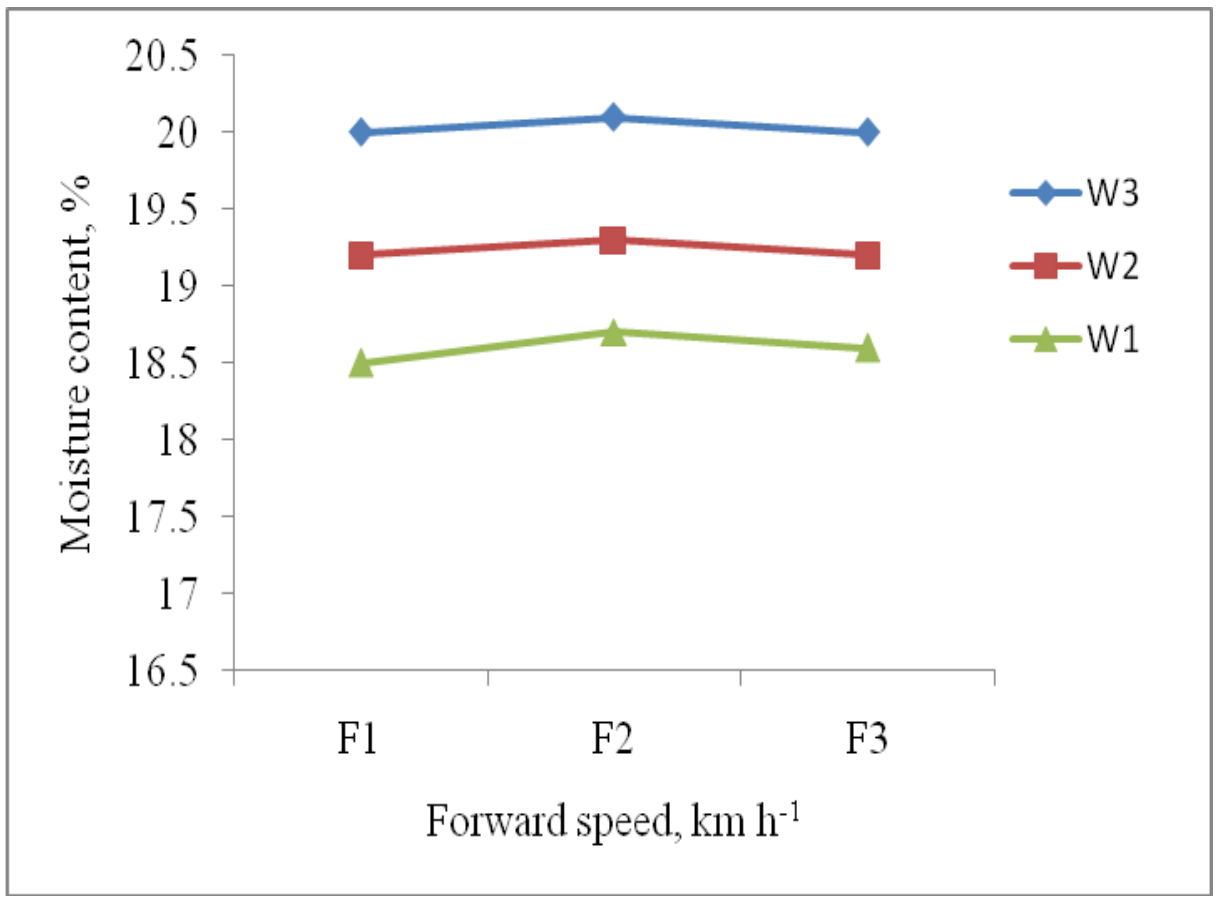

Fig.4 Effect of width of plastic mulch and forward speed on soil moisture content for silver color plastic mulch after 20 days of laying plastic mulch

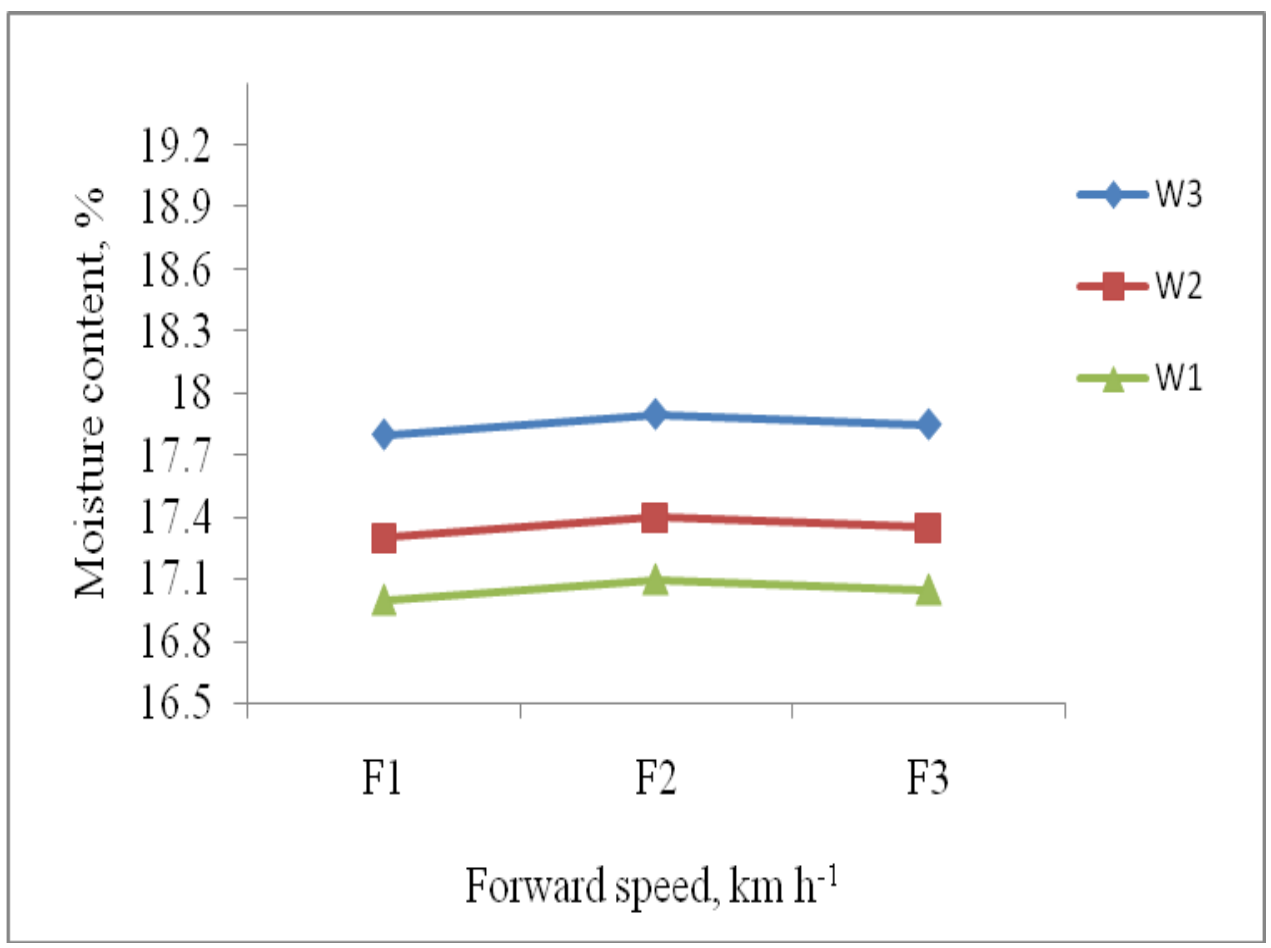


Fig.5 Effect of width of plastic mulch and forward speed on soil moisture content for black color plastic mulch after 20 days of laying plastic mulch

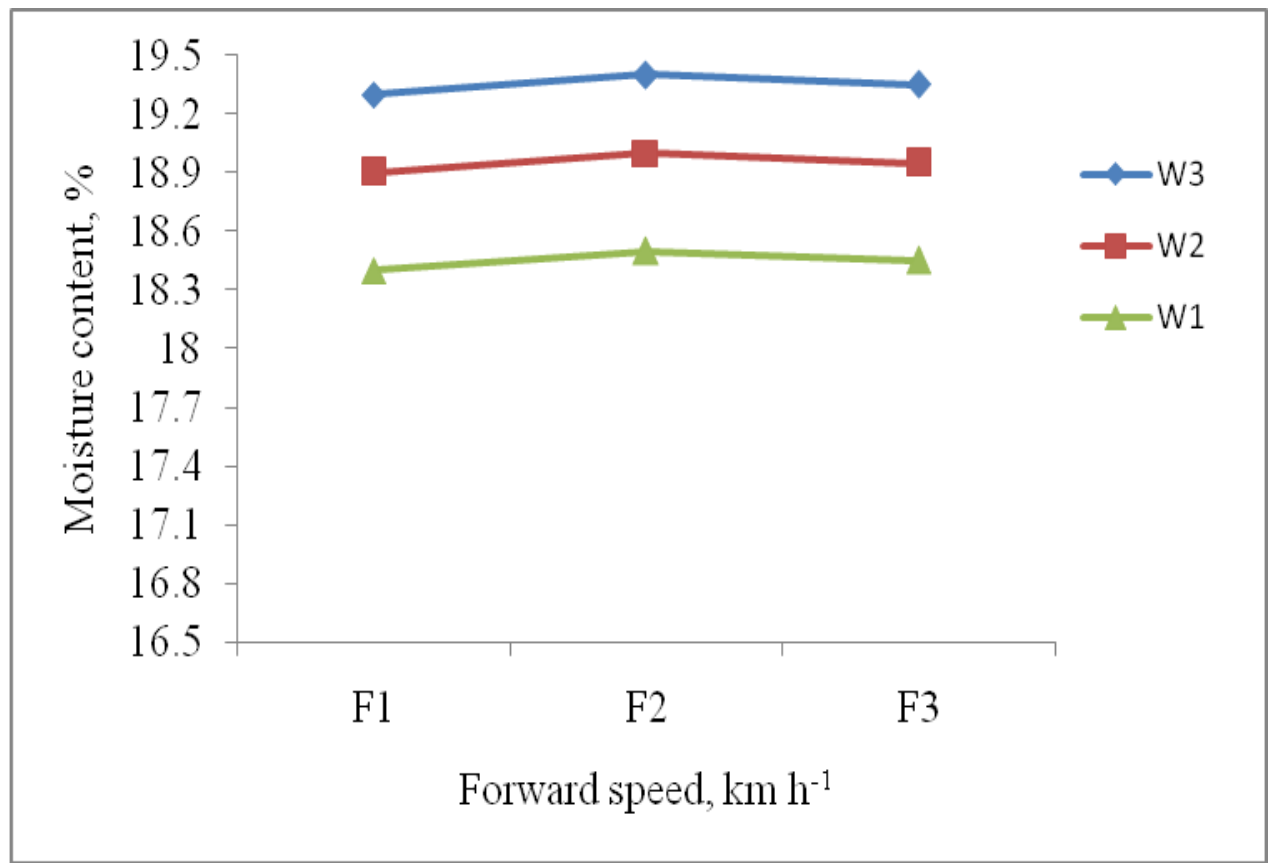

Fig.6 Effect of width of plastic mulch and forward speed on soil moisture content for silver color plastic mulch after 30 days of laying plastic mulch

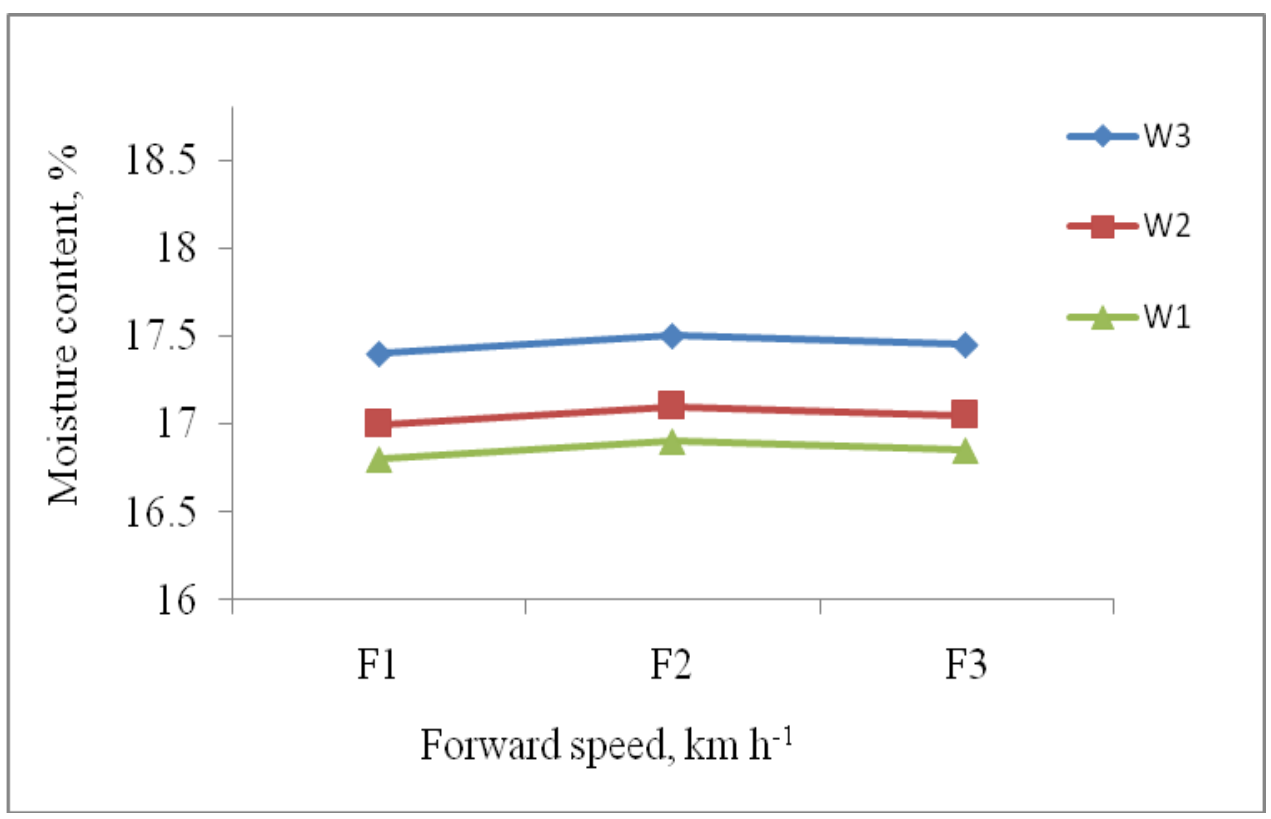


Fig.7 Effect of width of plastic mulch and forward speed on soil moisture content for black color plastic mulch after 30 days of laying plastic mulch

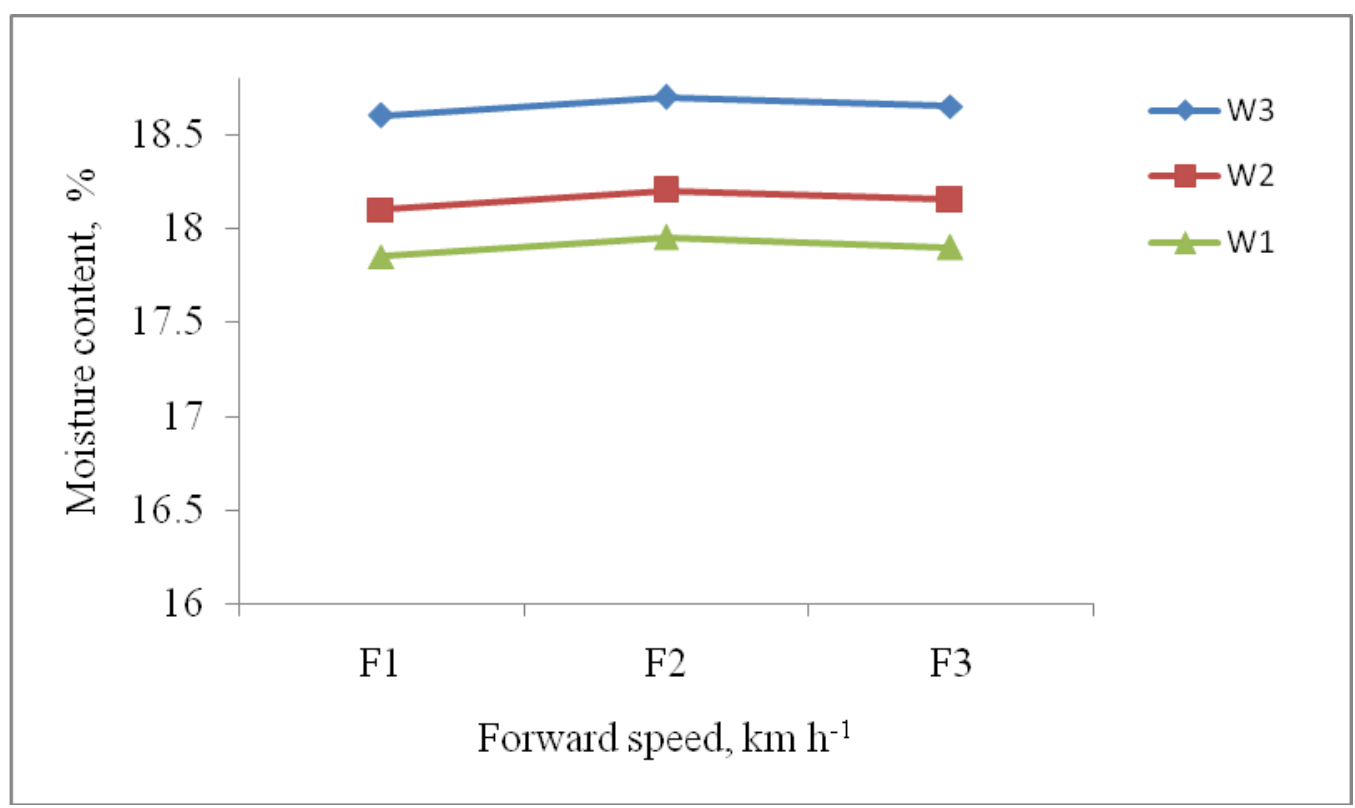

The effect of type of material, width of plastic mulch and forward speed on moisture content of soil at 2.0, 3.0 and $4.0 \mathrm{~km} \mathrm{~h}^{-1}$ speed after 20 days of plastic mulching are presented in Figure 4 and 5 respectively. It was observed that, moisture content increased as the width of the material increased with the two types of materials. However, higher moisture content was observed with the black colored plastic mulch with $1200 \mathrm{~mm}$ width of plastic mulch at all the forward speeds.

Effect of operational parameters viz. type of material, width of plastic mulch and forward speed on soil moisture content after 30 days of laying plastic mulch

Effect of operational parameters viz. type of material, width of plastic mulch and forward speed on soil moisture content after 30 days of laying plastic mulch are presented in Table 5. It was observed that, the soil moisture content with silver colored plastic mulch varied from $16.80 \%$ to $17.50 \%$ with different widths of plastic mulch and at different forward speeds. Maximum soil moisture content of $17.50 \%$ was recorded at a forward speed of $3.0 \mathrm{~km} \mathrm{~h}^{-1}$ with $1200 \mathrm{~mm}$ width of plastic mulch while it was minimum $16.80 \%$ at forward speed of $2.0 \mathrm{~km} \mathrm{~h}^{-1}$ with $900 \mathrm{~mm}$ width of plastic mulch. It was also observed that, with black colored plastic mulch the soil moisture content varied in the range of $17.85 \%$ to $18.70 \%$ with different width of plastic mulch and at different forward speeds.

Maximum moisture content of $18.70 \%$ was recorded at forward speed of $3.0 \mathrm{~km} \mathrm{~h}^{-1}$ with $1200 \mathrm{~mm}$ width of plastic mulch while it was minimum $17.85 \%$ at forward speed of $2.0 \mathrm{~km}$ $\mathrm{h}^{-1}$ with $900 \mathrm{~mm}$ width of plastic mulch. The effect of type of material, width of plastic mulch and forward speed on moisture content of soil after 30 days have been presented in Figure 6 and 7, respectively. It was observed that, the soil moisture content increased as the width of the material increased with the two types of materials. However, higher moisture content was observed in black colored plastic mulch with $1200 \mathrm{~mm}$ width of plastic mulch at all the forward speeds. 
In conclusion, a tractor operated plastic mulch laying equipment was developed to mechanize the conventional plastic mulching. The soil moisture content was found higher with $3.0 \mathrm{~km} \mathrm{~h}^{-1}$ tractor speed due to optimum contact and tightness between plastic mulch and the soil beds. Theoretical field capacity of tractor operated plastic mulch laying was found to be $0.36 \mathrm{ha} \mathrm{h}^{-1}$. Effective field capacity of tractor operated plastic mulch laying was found to be $0.24 \mathrm{ha} \mathrm{h}^{-1}$.

\section{References}

Anonymous, 1995, RNAM test codes and procedures for farm machinery, economic and social commission for Asia and Pacific Regional Network for Agriculture machinery, Bangkok.

Heipner A. S., Schmidt and Von E. B., 2005. Comparison of plastic mulch films with different optical properties for soil covering in horticulture: test under simulated environmental conditions. Journal of science and food agriculture., 85: 539-548.

Jimenez L., Martina M. and Ibarrab M., 2004. The effect of plastic mulch and row covers on the growth and physiology of cucumber: Australian Journal of Experimental Agriculture. 44: 91-94.

Joel F. R., 1995, Polymer science and technology: introduction to polymer science. 3rd edn. Prentice Hall, Upper Saddle River, p: 4-9.

Kepner R. A., Roy B and Barger, E. L., 2005. Principles of Farm Machinery. CBS Publishers \& Distributers (Pvt.) Ltd., New Delhi. P: 133.

Manian R., Kathirvel K., Reddy A and Senthilkumar T., 2004. Development and evaluation of weeding cum earthing up equipment for cotton. AMA, 35(2): 21-25.

Mehta M. L., Verma S. R., Mishra S. R and Sharma V. K., 2005. Testing and evaluation of agricultural machinery. Daya Publishing House, Delhi-100 035.

Sahay J., 2006. Elements of Agricultural Engineering., Standard Publishers Distributors. 1705-B, Nai Sarak, Delhi110006.

Scott G and Gilead D., 1995. Degradable polymers: principles and applications. Kluwer Academic/Chapman and Hall.

Tarara J. M., 2000. Microclimate modifications with plastic mulch: Hort. Science: 35(2):169-180.

\section{How to cite this article:}

Siddesh Marihonnappanavara, M. Veerangouda, K.V. Prakash, Sunil Shirwal and Maheshwara Babu, B. 2018. Performance Evaluation of Tractor Operated Plastic Mulch Laying Equipment for Black and Silver Colored Plastic Mulches. Int.J.Curr.Microbiol.App.Sci. 7(12): 2411-2422. doi: https://doi.org/10.20546/ijcmas.2018.712.274 